\title{
RELATIONSHIPS BETWEEN PSYCHOLOGICAL CHARACTERISTICS AND SPORT PERFORMANCE IN ORIENTEERING
}

\author{
Zshivka Zsheliaskova-Koynova \\ NSA "VassilLevski", Sofia, Bulgaria
}

\begin{abstract}
Summary
Introduction. Despite the fact that orienteering is one of the very popular individual sports in Bulgaria and all over the world, there is a lack of research on personality characteristics related to the competitive performance in orienteering. This is why the aim of the present study was to explore the relationships between some psychological characteristics (personality characteristics, sport motivation, sport confidence) and sport performance in orienteering. Method. The subjects were 35 Bulgarian orienteers (21 males, 14 females) who compete in Elite group. They completed 5 psychological tests (the Bulgarian versions of EPQ, STAI-Y, SMS, AMS-Sport, TSCI), measuring a total of 19 psychological characteristics. Sport performance in orienteering was operationalized as the average number of points earned from National competitions (by BFO rules) during 2 consecutive years. Results. The results of the correlation analysis indicated that the psychological characteristics with highest level of association with sport performance in Elite group were trait sport confidence, striving for success (SS), fear of failure (FF), hope (SS - FF) and amotivation. Discussion. High level of trait sport confidence, high hope and low amotivation correspond to higher level of sport performance in orienteering. Similar findings are reported by Bund (2001); Elbe \& Beckmann (2006), Coetzee, Grobbelaar \& Gird (2006), Zuber \& Conzelman (2014) in other sports. Conclusion. The results of the study demonstrate the necessity to modulate psychological preparation of young orienteers by means of encouraging self-confidence and approach motivation, simultaneously creating conditions for decreasing avoidance motivation in sport.
\end{abstract}

Keywords: performance, orienteering, personality, motivation, confidence

\section{Introduction}

Despite the fact that orienteering is one of the very popular individual sports in Bulgaria and all over the world, there is a lack of research on personality characteristics related to the competitive performance in orienteering. In fact, there is only one publication related to personality characteristics of orienteers (Zsheliaskova-Koynova, 1991). This is why the aim of the present study was to explore the relationships between some psychological characteristics (personality characteristics, sport motivation, sport confidence) and sport performance in orienteering.

\section{Method}

The subjects were 35 Bulgarian orienteers ( 21 males, 14 females) who compete in Elite group (aged 20-43, M=27.5). They completed 5 psychological tests - the Bulgarian versions of EPQ (Eysenck \& Eysenck, 1975; Bulgarian version by Паспаланов, Щетински и Айзенк, 1984), STAI-Y (Spielberger, Gorsuch, \& Lushene, 1970; Bulgarian version by Щетински и Паспаланов, 1989), SMS (Pelle- tier et al., 1995; Bulgarian version by Муховски, 2004), AMS-Sport (Elbe, Wenhold, \& Müller, 2005; Bulgarian version by Желязкова-Койнова, 2012), TSCI (Vealey, 1986; Bulgarian version by Желязкова-Койнова и Савчева, 2008), measuring a total of 19 psychological characteristics:

1. Eysenck's Personality Questionnaire (EPQ) - extroversion, neuroticism, psychoticism and lie (social desirability);

2. State and Trait Anxiety Inventory - form $Y$ (STAI-Y) - trait anxiety;

3. Sport Motivation Scale (SMS) - amotivation, extrinsic motivation (external, introjected and identified) and intrinsic motivation (intrinsic motivation - to know, intrinsic motivation for accomplishment and intrinsic motivation for stimulation).

4. Achievement Motives Scale - Sport (AMSSport) - striving for success (SS), fear of fail- 
ure (FF), hope (SS-FF), and total achievement motivation (SS+FF).

5. Trait Sport Confidence Inventory (TSCI) trait self-confidence in sport.

Sport performance in orienteering was operationalized as the average number of points earned from National competitions (by the rules of Bulgarian Federation of orienteering - БФО, 2010) during the year of the study. According these rules, for every position above $21^{\text {th }}$ it is given certain amount of points, and for lower placement it is given zero points.

\section{Results}

The descriptive statistics is presented in Table 1.

The comparison of the data to the norms of the tests shows that the measured values are in the average range according to the norms of the Bulgarian versions of the EPQ, AMS and TSCI (Паспаланов, Щетински и Айзенк, 1984 и Пенев, 2012; Желязкова-Койнова, Савчева, 2008; Желязкова-Койнова, 2012). The level of trait anxiety in elite orienteers is low, compared to the norms of the Bulgarian version of STAI-Y (Щетински и Паспаланов, 1989).
The intrinsic motivation in this sample is stronger than the extrinsic motivation, which is typical for amateur sport. Especially low are the values of external regulation of behavior. The highest value is the value of Intrinsic motivation for stimulation. All this represents sport motivation that is self-determined in very big extent. At the same time, the introjected motivation is quite strong in the sample, it is the second strongest type of motivation and its value is higher than the values of the other two types of intrinsic motivation. This means that the self-imposed duty and moral obligations represent very important motivation for the Bulgarian elite orienteers. Many of them are members of the National team and all of them are the most important competitors who earn the financing of their clubs (according to the rules of the Ministry of youth and sport and BFO). Similar are the findings of Домусчиева-Роглева, Мутафова-Заберска и Янчева (2013) who studied wrestling competitors and registered heightened level of introjected motivation amongst top ranked female wrestlers; and of Losa Iglesias et al. (2016), who studied Spanish Ultramarathon runners and showed that the level of introjected motivation was the highest point of their motivational profile in both males and females.

Table 1. Descriptive statistics of the sample data.

\begin{tabular}{|l|l|l|l|l|l|}
\hline Variables & MEAN & SD & Minimum & Maximum & Range \\
\hline Trait sport self-confidence & 85.66 & 15.27 & 49 & 113 & 64 \\
\hline Motive to achieve success & 34.89 & 6.17 & 16 & 45 & 29 \\
\hline Motive to avoid failure & 11.37 & 8.26 & 1 & 39 & 38 \\
\hline Hope & 23.51 & 13.4 & -23 & 44 & 67 \\
\hline Total achievement motivation & 46.26 & 5.76 & 27 & 57 & 30 \\
\hline Need for approval & 8.12 & 3.85 & 1 & 15 & 14 \\
\hline Extroversion & 14.12 & 4.83 & 1 & 20 & 19 \\
\hline Neuroticism & 7.82 & 6.62 & 0 & 19 & 19 \\
\hline Psychoticism & 3.79 & 2.85 & 0 & 10 & 10 \\
\hline Trait anxiety & 36 & 8.15 & 21 & 53 & 32 \\
\hline Amotivation & 1.66 & 0.69 & 1 & 3.5 & 2.5 \\
\hline External regulation & 3.19 & 1.59 & 1 & 6.75 & 5.75 \\
\hline Introjected rmotivation & 5.96 & 1.2 & 3 & 7 & 4 \\
\hline Identified rmortivation & 5.49 & 1.16 & 2.75 & 7 & 4.25 \\
\hline Intrinsic motivation - to know & 5.09 & 1.02 & 3 & 7 & 4 \\
\hline Intrinsic motivation - to accomplish & 5.47 & 1.07 & 3 & 7 & 4 \\
\hline Intrinsic motivation for stimulation & 6.12 & 0.79 & 3.75 & 7 & 3.25 \\
\hline Extrinsic motivation & 4.88 & 1.03 & 2.33 & 6.92 & 4.59 \\
\hline Intrinsic motivation & 5.50 & 0.89 & 3.33 & 6.67 & 3.34 \\
\hline Orienteering performance & 29.18 & 11.60 & 0 & 49.33 & 49.33 \\
\hline
\end{tabular}


The results of correlational analysis are presented in Table 2.

The results of the correlation analysis indicate that the psychological characteristics with highest level of association with sport performance in Elite group are hope (SS - FF) - $\mathrm{r}=0.529$ (strong association), trait sport confidence $-\mathrm{r}=0.489$ (moderate association) and amotivation - $\mathrm{r}=0.417$ (moderate association). That means that higher hope (i.e., high striving for success simultaneously with low fear of failure) corresponds to better performance in orienteering; also, higher sport confidence and lower amotivation are related to higher sport performance.

Table 2. Results of correlational analysis.

\begin{tabular}{|l|l|}
\hline Variables & $\begin{array}{l}\text { Correlation } \\
\text { with perfor- } \\
\text { mance }\end{array}$ \\
\hline Trait sport self-confidence & $0.489^{\star *}$ \\
\hline Motive to achieve success & $0.471^{\star}$ \\
\hline Motive to avoid failure & $-0.474^{\star}$ \\
\hline Hope & $0.529^{\star *}$ \\
\hline Total achievement motivation & -0.119 \\
\hline Need for approval (Lie) & 0.006 \\
\hline Extroversion & 0.133 \\
\hline Neuroticism & -0.053 \\
\hline Psychoticism & -0.050 \\
\hline Trait anxiety & -0.215 \\
\hline Amotivation & $-0.417^{\star}$ \\
\hline External regulation & 0.183 \\
\hline Introjected rmotivation & 0.130 \\
\hline Identified rmortivation & 0.041 \\
\hline Intrinsic motivation - to know & -0.091 \\
\hline Intrinsic motivation - to accomplish & 0.062 \\
\hline Intrinsic motivation for stimulation & 0.226 \\
\hline Extrinsic motivation & 0.163 \\
\hline Intrinsic motivation & -0.048 \\
\hline & \\
\hline
\end{tabular}

${ }^{*} \mathrm{p}<0.05,{ }^{* *} \mathrm{p}<0.01$

\section{Discussion}

The results of the study show that high level of trait sport confidence, high hope (combination of high level of striving for success and low level of fear of failure) and low amotivation correspond to higher level of sport performance in orienteering. Orienteers that are characterized by high hope, high self-confidence and low amotivation show higher competitive performance through the year and orienteers that are characterized by low self-confidence, low hope and higher amotivation compete worse.
It is well recognized that the self-confidence influences significantly and positively sport performance (Craft et al., 2003; Feltz, 1988; Moritz et al., 2000; Woodman \& Hardy, 2003). Moritz et al (2000) in their meta-review report average correlation of $r=0.26$ between domain-specific measures of self-efficacy, such as self-confidence, and sport performance. Craft et al. (2003) report mean effect size of $r=0.25$. Woodman and Hardy (2003) - of $\mathrm{r}=0.24$, Our results show similar trend but twice as big size effect, which could be explained by the size of the sample and by the fact that the subjects are elite athletes. As showed by Craft et al. (2003), the relationship of self-confidence and sport performance in elite European club athletes are much closer than in American college athletes and in PE students.

Thomassen and Halvari (1996) reveal significant positive relationship between striving for success and sport performance while at the same time the fear of failure correlates negatively with sport performance. Striving for success and fear of failure are important predictors of the training frequency - higher fear of failure and low striving for success are related to reduced frequency of practice (Gabler, 1981). The positive influence of striving for success and hope on the sport performance is showed by Elbe \& \& Beckmann (2006), Coetzee, Grobbelaar \& Gird (2006), Zuber \& Conzelman (2014). Similar findings - positive relationship between striving for success and sport performance and negative relationship between fear of failure and sport peerformance,- are presented in other studies on Bulgarian orienteers (ЖелязковаКойнова, Стоянова, 2014), handball- and basketball players (Желязкова-Койнова, Върбанов, 2012; Желязкова-Койнова, Тодорова, 2014).

Many studies identified significant negative relationship between trait anxiety and sport performance (Kleine, 1990; Spielberger, 1990; Eysenck \& Calvo, 1992: Eysenck et al., 2007). In our sample this relationship is negative but nonsignificant - a results that is not surprising if we take into account that the level of trait anxiety is low in the sample.

And, at the end, significant negative relationship between amotivation and sport performance indicates that engaged, motivated orienteers who do not intend to quit sport, showing very low levels of amotivation, compete better than the orienteers 
who have doubts and some amount of demotivation. Similar results obtained Брънзова (2015) in basketball players.

\section{Conclusion}

The results of the study demonstrate the necessity to modulate psychological preparation of young orienteers by means of encouraging self-confidence and approach motivation, simultaneously creating conditions for decreasing avoidance motivation in sport. Psychological work with parents and coaches should allow to organize the best possible conditions for development of appropriate motivational atmosphere.

\section{References:}

Брънзова, А. Изследване на мотивацията на елитни състезатели по баскетбол. (2015). Дисертация, НСА, C.

\section{БФО (2010)}

Наредбата за точкуване на състезателите като критерии за разпределение на годишните финансови средства от МФВС, утвърдена от УС на БФО с Решение № 7, Протокол № 1/23.01.2010, available at: http://orienteering.bg/get.phpile=\%D0\%9A\%D1\%80 \%D0\%B8\%D1\%82\%D0\%B5\%D1\%80\%D0\%B8\%D0 \%B8\%20\%D0\%B7\%D0\%B0\%20\%D1\%82\%D0\%BE\% D $1 \% 87 \%$ D0\%BA\%D1\%83\%D0\%B2\%D0\%B0\%D0\%BD\%D0\%B5.pdf\&id=428

(accessed 28.08.2017).

Домусчиева-Роглева, Мутафова-Заберска, Ю., Янчева, М. (2014). Вътрешна и външна мотивация при спортисти. Сборник научни доклади от Седми национален конгрес по психология, София, Дружество на психолозите, 1501-1513.

Пенев, С. (2012). Нова стандартизация на теста на Айзенк. Научни трудове на Русенския университет т. 51, серия $10,35-38$

Желязкова-Койнова, Ж. Адаптация на тест за изследване на мотивацията за постижение при спортисти (Elbe, Wenhold \& Müller, 2005). Личност. Мотивация. Спорт. Т. 17, НСА-ПРЕС, С., 2012, 186196.

Желязкова-Койнова, Ж., Е. Савчева. Адаптация на теста на Р. Вийли (Vealey, 1986) за изследване на личностната спортна увереност В: Личност, мотивация, спорт, т. 13, НСА Прес, С., 2008, 66-73

Желязкова-Койнова, Ж., Върбанов, И. (2012). Влияние на мотивационни и темпераментови характеристики върху спортното постижение при хандбалистки. В сб. „Съвременни тенденции на физическото възпитание и спорта”, Университетско издателство „Климент Охридски”, 291-297.

Желязкова-Койнова, Ж., Стоянова, К. (2014). Влияние на темпераментови и мотивационни особености върху спортното постижение при състезателите от възрастова група Мъже 21 по спортно ориентиране. Спорт и наука, Извънреден брой 1, 51-57.

Желязкова-Койнова, Ж., Тодорова, В. (2014). Влияние на темпераментови характеристики, мотивация за постижение и психологически умения върху игровата ефективност при висококласни баскетболистки. Съвременни тенденции, проблеми и иновации във физическото възпитание и спорта във висшите училища. Издателски комплекс УНСС, 150-165.

Паспаланов, И., Щетински, Д., Айзенк, С. (1984). Българска адаптация на личностния въпросник на Х. Айзенк. Психология, 5, 279-292

Щетински, Д., Паспаланов, И. (1989). Методическо пособиеза работасбългарската форма на въпросника за оценка на тревожността на Ч. Спилбъргър (STAI - форма Y). С., БАН, 1989

Coetzee, B., Grobbelaar, H. W., \& Gird, C. C. (2006). Sport psychological skills that distinguish successful from less successful soccer teams. Journal of Human Movement Studies, 51(6), 383-402.

Craft, L. L., Magyar, T. M., Becker, B. J., \& Feltz, D. L. (2003). The relationship between the Competitive State Anxiety Inventory-2 and sport performance: A meta-analysis. Journal of sport and exercise psychology, 25(1), 44-65.

Elbe, A.-M., \& Beckmann, J. (2006). Motivational and self-regulatory factors and sport performance in young elite athletes. In D. Hackfort \& G. Tenenbaum (Eds.), Essential processes for attaining peak performance. Aachen: Meyer \& Meyer Sport, 137-157.

Elbe, A.-M., Wenhold, F., \& Müller, D. (2005). Zur Reliabilität und Validität der Achievement Motives ScaleSport: Ein Instrument zur Bestimmung des sportspezifischen Leistungsmotivs [The reliability and validity of the Achievement Motives Scales - Sport: An instrument for the measurement of sport-specific achievement motivation]. Zeitschrift für Sportpsychologie, 12, 57-68.

Eysenck, M. W., \& Calvo, M. G. (1992). Anxiety and performance: The processing efficiency theory. Cognition \& Emotion, 6(6), 409-434.

Eysenck, M.W., Derakshan, N., Santos, R., Calvo, M.G.(2007). Anxiety and cognitive performance: Attention control theory. Emotion,7, 336-353.

Eysenck, H. J., \& Eysenck, S.B.G. (1975). Manual of the Eysenck Personality Questionnaire. London: Hodder \& Stoughton

Feltz, D. L. (1988). Self-confidence and sports performance. Exercise and sport sciences reviews, 16(1), 423458.

Gabler, H. Motivationale Aspekte sportlicher Handlungen. In: H. Gabler, J. R. Nitsch \& R. Singer. Einführung in die Sportpsychologie. Hofmann, Schorndorf, 1995, 64-102

Kleine, D. (1990). Anxiety and sport performance: A meta-analysis. Anxiety research, 2(2), 113-131.

Losa Iglesias, M. E., Vallejo, B., Rodriguez Vazquez, R (2016). The Motivation of Spanish Ultramarathon Runners Sports Coaching: Peak Performance (Goal Setting, Motivation, Skill Acquisition). Annals of Sports Medi- 
cine and Research, 3(4), 1072.

Moritz, S. E., Feltz, D. L., Fahrbach, K. R., \& Mack, D. E. (2000). The relation of self-efficacy measures to sport performance: A meta-analytic review. Research quarterly for exercise and sport, 71(3), 280-294.

Pelletier, L. G., Tuson, K. M., Fortier, M. S., Vallerand, R. J., Briere, N. M., \& Blais, M. R. (1995). Toward a new measure of intrinsic motivation, extrinsic motivation, and amotivation in sports: The Sport Motivation Scale (SMS). Journal of Sport and Exercise Psychology, 17(1), 35-53.

Spielberger, C.D. (1990). Stress and anxiety in sports. In: Hackfort, Dieter, and Charles D. Spielberger, eds. Anxiety in sports: an international perspective. Taylor \& Francis, 3-17.

Spielberger, C.D, Gorsuch, R.L., Lushene, R.E. (1970). Manual for the State-Trait Anxiety Inventory. Consulting Psychologist Press, Palo Alto, California

Thomassen, T.O.\& Halvari, H. (1996). Achievement motivation and involvement in sport competitions. Percep- tual and Motor Skills, 83, 1996, 1363-1374.

Vealey, R. S. (1986). Conceptualization of sport-confidence and competitive orientation: Preliminary investigation and instrument development. Journal of sport psychology, 8(3), 221-246.

Woodman, T., \& Hardy, L. (2003). The relative impact of cognitive anxiety and self-confidence upon sport performance: A meta-analysis. Journal of sports sciences, 21(6), 443-457.

Zsheliaskova-Koynova, Z. (1991). Some Personality Characteristics of Elite Orienteers. Scientific Journal of Orienteering, 7, 18-33.

Zuber, C., \& Conzelmann, A. (2014). The impact of the achievement motive on athletic performance in adolescent football players. European journal of sport science, $14(5), 475-483$.

Contact information with the corresponding author:

Associate Professor Zshivka Zsheliaskova-Koynova, PhD, zshivka@gmail.com, 0892299850 